\title{
The efficacy of vacuum-ultraviolet light disinfection of some common environmental pathogens
}

\author{
Wai Szeto', W. C. Yam², Haibao Huang ${ }^{3}$ and Dennis Y. C. Leung ${ }^{1 *}$ (D)
}

\begin{abstract}
Background: This study is to elucidate the disinfection effect of ozone producing low-pressure Hg vapor lamps against human pathogens. Ozone producing low-pressure Hg vapor lamps emit mainly $254 \mathrm{~nm}$ ultraviolet light C (UVC) with about 10\% power of Vacuum-ultraviolet (VUV) light at $185 \mathrm{~nm}$. The combination of UVC and VUV can inactivate airborne pathogens by disrupting the genetic materials or generation of reactive oxygen species, respectively. In this study, inactivation of common bacteria including Escherichia coli ATCC25922 (E. coli), Extended Spectrum Beta-Lactamaseproducing E. coli (ESBL), Methicillin-resistant Staphylococcus aureus (MRSA) and Mycobacterium tuberculosis (MTB), and that of influenza A viruses $\mathrm{H} 1 \mathrm{~N} 1$ and $\mathrm{H} 3 \mathrm{~N} 2$ under the radiation from ozone producing low-pressure $\mathrm{Hg}$ vapor lamps was examined. Log reduction values at different treatment durations were determined.

Methods: In vitro tests were carried out. Various bacterium and virus suspensions were added onto nitrocellulose filter papers and subjected to the illumination from ozone producing low-pressure Hg vapor lamps. The extents of pathogen inactivation at different illumination times were investigated by conducting a series of experiments with increasing duration of illumination. $\log 10$ reduction in $\mathrm{CFU} / \mathrm{ml}$ and reduction at $\log 10\left(\mathrm{TCID}_{50}\right)$ were respectively measured for bacteria and viruses. The disinfection effectiveness of this type of lamps against the pathogens under the environment with a moderate barrier to light was therefore evaluated.
\end{abstract}

Results: Ozone producing low-pressure Hg vapor lamp successfully inactivated these human pathogens. Nevertheless, among these pathogens, disinfection of MTB required more intense treatment. In the best tested situation, 3-log10 inactivation of pathogens can be achieved with $\leq 10 \mathrm{~min}$ of VUV treatment except MTB which needed about 20 min. This demonstrated the high resistance against UV disinfection of MTB.

Conclusions: Following the criteria that valid germicidal results can be reflected with 3-log10 inactivation for bacteria, 4$\log 10$ inactivation for viruses and 5-log10 inactivation for MTB, most of the bacteria required $\leq 10$ min of VUV treatment, 20 min for the influenza viruses while MTB needed about 30 min VUV treatment. This indicated that VUV light is an effective approach against different environmental microorganisms.

Keywords: Disinfection, Microorganism, Ozone, VUV, IAQ, Influenza, Tuberculosis, ESBL, MRSA

\footnotetext{
* Correspondence: ycleung@hku.hk

${ }^{1}$ Department of Mechanical Engineering, The University of Hong Kong, Hong

Kong, China

Full list of author information is available at the end of the article
}

(c) The Author(s). 2020 Open Access This article is distributed under the terms of the Creative Commons Attribution 4.0 International License (http://creativecommons.org/licenses/by/4.0/), which permits unrestricted use, distribution, and reproduction in any medium, provided you give appropriate credit to the original author(s) and the source, provide a link to the Creative Commons license, and indicate if changes were made. The Creative Commons Public Domain Dedication waiver (http://creativecommons.org/publicdomain/zero/1.0/) applies to the data made available in this article, unless otherwise stated. 


\section{Background}

Indoor air quality (IAQ) has a significant influence on health, comfort and well-being of building occupants. It has been demonstrated that poor IAQ could jeopardize health and well-being, which in turn will affect the quality of work and ultimately lower the productivity of workers [1].

One major source of indoor air pollution is the presence of micro-organisms, which could cause even more serious problems than some organic and inorganic air contaminants. This is particularly more phenomenal in cases of inadequate ventilation, as the condensation in ventilation system can act as a breeding ground for harmful bacteria which are dispensed through the ventilation ducts. Environmental airborne bacteria such as Pseudomonas aeruginosa, Streptomyces albus, Bacillus subtilis and complex populations of micro-organisms within normal flora were all etiological agents to hypersensitivity pulmonary diseases. Several additional infectious agents such as Legionella pneumophila and Mycobacterium tuberculosis (MTB) pose even more grave concerns to the IAQ, as these airborne pathogenic bacteria are known to cause severe illness in humans. Meanwhile, viruses such as influenza virus were originally thought to be only transmitted from person to person via aerosols of body fluids. However, in a recent study conducted by Weistein et al. [2], the production of infectious droplet nuclei of diameter $<5 \mu \mathrm{m}$ could remain suspended and disseminated by air current to infect a susceptible host. A good and reliable disinfection system, therefore, is required to disinfect the airborne microorganisms in order to maintain good IAQ.

Adopting vacuum-UV (VUV) lamps, for instance, the ozone producing low-pressure $\mathrm{Hg}$ vapor lamps, can be an effective mean of disinfecting the airborne microorganisms. Many existing infection control products use low pressure mercury vapor lamps as light source. This is a source of high energy photons with low cost. Recently, pulsed xenon light source technology emitting a broad spectrum (200-300 nm) of UV light is an emerging alternative to low pressure mercury vapor lamps that allows much faster surface disinfection because of the high peak power [3]. Nevertheless, the pulsed nature of this technology would limit its use in continuous air disinfection system. Electrical discharge of low pressure mercury vapor mainly emits 254 nm ultraviolet light C (UVC) and 185 $\mathrm{nm}$ VUV light. However, existing products mainly use the lamps with doped quartz envelope that absorbs $185 \mathrm{~nm}$ photons to prevent the formation of potentially dangerous ozone. Nevertheless, ozone is also a powerful disinfectant and the valuable disinfection opportunity of the $185 \mathrm{~nm}$ VUV light becomes waste heat.

Ozone is an issue that bothers on safety if it remains in the output of an air treatment system. However, ozone can be easily destroyed before leaving the air treatment system if proper catalyst is adopted [4, 5]. Also, some photocatalysts can utilize and destroy ozone in addition to its photocatalytic activity [6].

The $254 \mathrm{~nm}$ UVC light adopted in conventional infection control products can disinfect the illuminated objects since the $254 \mathrm{~nm}$ radiation can disrupt the genetic materials of airborne pathogens and render them inviable [7].VUV has an even stronger ionizing power than UVC light and can generate high concentration reactive species such as ozone and $\mathrm{OH}$ radicals [7]. In other words, apart from direct illumination, VUV can inactivate bacterial growth by the radicals generated during VUV irradiation. Therefore, adopting VUV lamps can enhance the air disinfection capability of air cleaning systems. A previous study [4] conducted by Huang et al. demonstrated that $64 \%$ toluene removal with VUV irradiation alone and the use of photocatalyst enhanced the toluene removal from 64 to $82 \%$. The experiment adopting UVC lamps and the use of photocatalyst removed only $14 \%$ of toluene. The result demonstrated that VUV light could be an effective measure for chemical degradation in ventilation systems. When it comes to disinfection, extensive research has been carried out on UVC light and effective destruction of both airborne [8-20] and other human pathogens [21-29] has been shown. Nevertheless, disinfection using VUV light has attracted very little attention. This would be caused by the relative low prevalence of VUV light sources. Kim et al. [30] found that the disinfection time required to attain the same extent of inactivation of aerosolized MS2 bacteriophage, using low pressure mercury vapor lamps with both $254 \mathrm{~nm}$ UVC and $185 \mathrm{~nm}$ VUV output was much shorter than the lamps with $254 \mathrm{~nm}$ UVC only. The disinfection time of ozone only (without UV) process at ozone concentrations equivalent to the ozone level generated by the mercury vapor lamps was also significantly faster than using lamps with $254 \mathrm{~nm}$ emission only. Besides, Huang et al. [4] reported the inactivation of $E$ coli by low pressure mercury vapor lamps. Additionally, some researchers tested the disinfection of water with VUV light and it was reported that the efficiency was quite low compared to disinfection with UVC light [31, 32]. The reason is due to the low penetration power of VUV light in water [33]. Moreover, the disinfection of human pathogens by VUV light was rarely reported. In our opinion, only Christofi et al. [34] reported the disinfection of the microbial films of 3 types of pathogenic bacteria using ozone producing low-pressure $\mathrm{Hg}$ vapor lamps. Therefore, the effect of VUV light against human pathogens is yet to be elucidated. In this study, we evaluated the germicidal effect of VUV light on common bacteria including Escherichia coli ATCC25922 (E. coli), Extended Spectrum BetaLactamase-producing E. coli (ESBL), Methicillin-resistant Staphylococcus aureus (MRSA) and Mycobacterium tuberculosis (MTB), and that on influenza viruses $\mathrm{H} 1 \mathrm{~N} 1$ and 
H3N2. Influenza viruses and MTB are inherent airborne pathogens while E. coli ATCC25922 is always the first indicator organism to monitor disinfection efficacy. The more drug resistant ESBL and MRSA were chosen as examples to monitor disinfection efficacy on human pathogens. Some suspensions of these bacteria and viruses were absorbed into nitrocellulose filter papers during the experiments and the disinfection under the environment with a moderate barrier to light was evaluated.

\section{Methods}

\section{UV irradiation}

To evaluate the biocidal effect of VUV light, bacteria and viruses were irradiated with a pair of hot cathode low pressure mercury vapor lamps. The lamps were $10 \mathrm{~W}, \mathrm{U}$ VIX brand, ZW10D15Y, ozone generating. The distance between the light source and the microorganisms was approximately $5 \mathrm{~cm}$ and the UV intensities at $254 \mathrm{~nm}$ and $185 \mathrm{~nm}$, respectively measured by a ZDZ-1 UV-C meter and an ILT1400 radiometer were 21 and $2.3 \mathrm{~mW} / \mathrm{cm}^{2}$, respectively. To reduce the leakage of UV light and lampgenerated ozone to the surrounding, the lamps and the microorganisms under test were contained in a metal chamber during the experiments as shown in Fig. 1.

\section{Bacterial strains and inoculum preparation}

Following procedures were used to prepare bacterial samples for UV irradiation experiments.
Escherichia coli ATCC25922 (E. coli), extended Spectrum Beta-Lactamase-producing E. coli (ESBL) and methicillinresistant Staphylococcus aureus (MRSA)

Escherichia coli strain ATCC25922 (E. coli), fully susceptible to most antibiotics, was purchased from American Type Culture Collection (ATCC). Methicillin-resistant Staphylococcus aureus strain QC 5618 (MRSA) was provided as a Proficiency Program of Central Public Health Laboratory, Colindale, UK. Extended Spectrum BetaLactamase-producing E. coli strain MM1604 (ESBL) was provided as a Proficiency Program of Central Public Health Laboratory Service, Department of Health, Hong Kong.

E. coli and MRSA were inoculated onto Mueller-Hinton agar (BD Bioscience, CA, USA) plates and incubated overnight at $37^{\circ} \mathrm{C}$ to yield single colonies. Overnight cultures were prepared by inoculating single colonies of each bacterial strain into Brain Heart Infusion (BHI) broth (BD Bioscience, CA, USA). Bacterial suspension at early exponential phase was inoculated into $\mathrm{BHI}$ broth at $37^{\circ} \mathrm{C}$ for 2 h. The concentration of the bacterial suspension was then visually adjusted to McFarland standard 0.5. Test suspension was prepared by diluting the $0.5 \mathrm{McF}$ arland standard inoculum by 10 -fold and 100-fold. Actual bacterial count was calculated by back titration of the inoculum suspension. Purity of MRSA was checked by ChromID ${ }^{\circ}$ MRSA agar plate (BioMérieux SA, France) and the purities of E.coli and ESBL-producing E. coli were confirmed by MacConkey agar plate (Oxoid $^{\mathrm{TM}}$, Thermo Scientific, Massachusetts, United States).

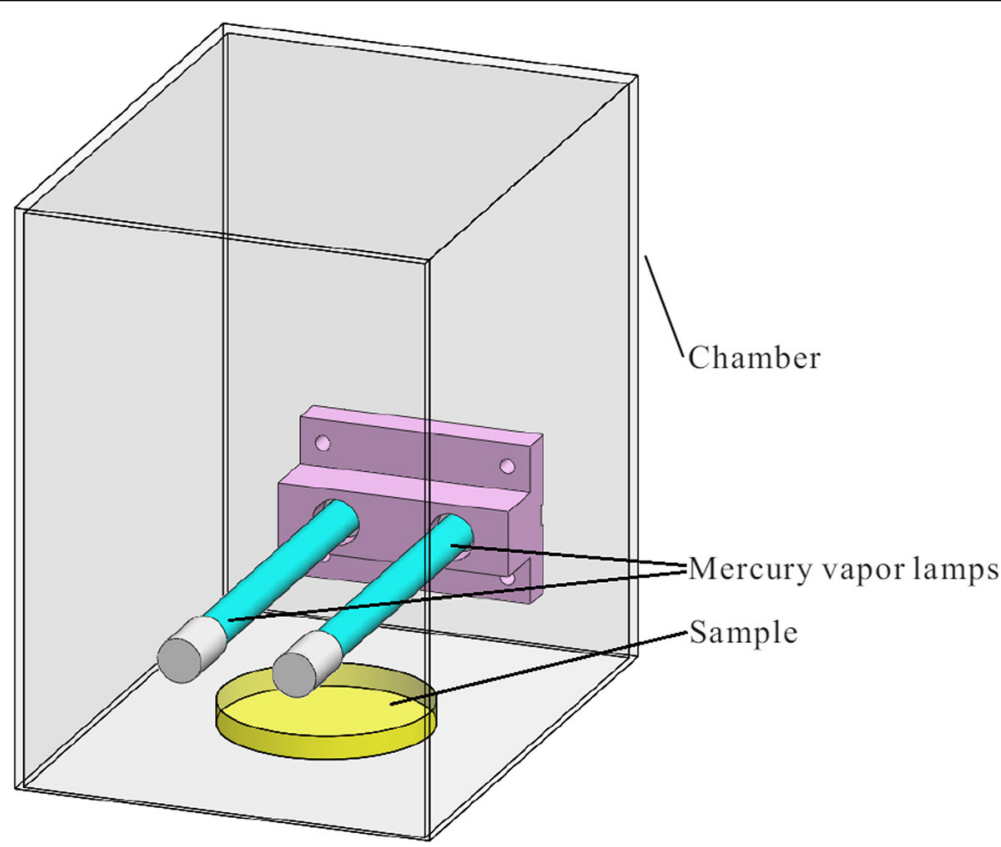

Fig. 1 The VUV illumination experiment 


\section{Mycobacterium tuberculosis (MTB)}

MTB H37Rv (ATCC27294) was selected as the model organism. Due to the infectivity and the risk of handling MTB, the experiments were conducted in the Biosafety Level-3 Laboratory of The University of Hong Kong.

MTB was first inoculated onto non-selective Middlebrook 7H11 agar (BD Bioscience, CA, USA) supplemented with $10 \%$ Oleic acid-Albumin-Dextrose-Catalase (OADC) and incubated at $37{ }^{\circ} \mathrm{C}$ with $5 \% \mathrm{CO}_{2}$ until single colonies were obtained. Mycobacterial colonies were resuspended into glass-bead Phospate-Buffered Saline with 0.1\% Tween 80. Inoculum was vortexed for $30 \mathrm{~s}$ to homogenize the bacterial suspension. Bacterial concentration was then adjusted to optical density at $600 \mathrm{~nm}=0.15-0.17$, which is equivalent to $0.5 \mathrm{McF}$ arland standard. Two test suspensions were prepared, which were $0.5 \mathrm{McF}$ arland standard inoculum and 10-fold diluted 0.5 McFarland suspensions. Actual MTB count was calculated by back titration of the inoculum suspension on Middlebrook 7H11 agar. Purity of MTB was checked by culturing the inoculums on blood agar to ensure no fungal and bacterial contamination, and on non-selective Middlebrook 7H11 agar to ensure there was no contamination by nontuberculous mycobacteria.

\section{Virus strains and cell lines}

H1N1 and H3N2

Following procedures were used to prepare viral samples for UV irradiation experiments.

H1N1 was isolated from the first swine flu patient in Hong Kong in 2009 by the Department of Microbiology, The University of Hong Kong. H3N2, a seasonal flu in Hong Kong, was generously provided by Prof. H.L. Chen, Department of Microbiology, The University of Hong Kong. MDCK (Madin-Darby canine kidney) cell line provided by CDC, USA, was used to cultivate H1N1 and $\mathrm{H} 3 \mathrm{~N} 2$ viruses.

Both seasonal influenza A viruses were cultured in MDCK cells in MEM (GiBCO) supplemented with TPCK-trypsin (Sigma-Aldrich, MO, USA). Virus-infected cells were harvested when almost all MDCK cells exhibited cytopathic effects. Infected cells and the conditioned media underwent one freeze-thaw cycle to release viral particles. The suspension was then centrifuged at $3000 \mathrm{rpm}$ for $5 \mathrm{~min}$, and supernatant containing viral particles was collected. Tissue culture infective dose $50\left(\mathrm{TCID}_{50}\right)$ was determined in a 96 well tissue culture plate using Reed Muench method. Virus stock was stored at $-80^{\circ} \mathrm{C}$ prior usage.

\section{UV disinfection experiments}

\section{VUV disinfection experiments of E. coli, ESBL and MRSA}

To analyze the bactericidal effect of VUV light, $2 \mathrm{~mL}$ of bacterial suspension was added onto the nitrocellulose filter and irradiated by VUV for 2, 5, 10 and $15 \mathrm{~min}$ at a distance of $5 \mathrm{~cm}$ at $25^{\circ} \mathrm{C}$. This distance was selected based on the consideration of the time of disinfection and temperature rise of the agar during the course of experiments. As each experiment was carried out inside a Level-2 Biosafety Cabinet, the $2 \mathrm{~mL}$ added suspension was carefully adjusted so that the filter remained moisted at the end of irradiation as dryness will reduce the viable count recovered from the filter.

The illuminated bacterial suspension and the nitrocellulose filter were vigorously washed by $10 \mathrm{~mL}$ Phosphatebuffered saline (PBS). The suspension was then serially diluted with PBS from $10^{0}$ to $10^{-4}$, and $100 \mu \mathrm{L}$ of each of the serially diluted bacterial suspensions was spread onto a Mueller-Hinton agar plate. Meanwhile, bacterial test suspensions without VUV illumination were spread onto Mueller Hinton agar to obtain the initial colony-forming units (CFU) before the use of VUV light disinfection as control.

All Mueller-Hinton agar plates were incubated overnight at $37{ }^{\circ} \mathrm{C}$. The resultant $\mathrm{CFU}$ in each test suspension reflected the viable bacterial count after different disinfection durations. The disinfection assay was carried out in triplicate for each bacterial strain.

\section{VUV disinfection experiments of Mycobacterium tuberculosis}

To investigate the minimum time required by VUV light for optimal MTB disinfection, test sets were used in which $2 \mathrm{~mL}$ concentration-adjusted MTB inoculums, added onto nitrocellulose filter papers, were illuminated by VUV for 10, 20, 30 and $45 \mathrm{~min}$.

The illuminated bacterial suspension and nitrocellulose filter were vigorously washed by $10 \mathrm{~mL}$ PBS, and the suspension was serially diluted $\left(10^{0}-10^{-4}\right)$. A total of $100 \mu \mathrm{L}$ of each diluted bacterial suspension was spread onto selective Middlebrook 7H11 agar supplemented with 10\% oleic albumin dextrose (OADC), 200,000 unit/ L Polymyxin B, $50 \mathrm{mg} / \mathrm{L}$ Carbenicillin, $10 \mathrm{mg} / \mathrm{L}$ Amphotericin $\mathrm{B}$ and $20 \mathrm{mg} / \mathrm{L}$ Trimethoprim Lactate. Bacterial inoculum without VUV illumination was used as MTB growth control and to determine the original viable bacterial count. Each test set was conducted in triplicate.

\section{VUV disinfection experiments of influenza viruses H1N1 and H3N2}

To analyze the virucidal effect of VUV light, $2 \mathrm{~mL}$ virus samples at $\sim 1 \times 10^{6} \mathrm{TCID}_{50} / \mathrm{mL}$ were added onto nitrocellulose filter papers and irradiated by vacuum ultraviolet light (VUV) for 5, 10, 15 and $20 \mathrm{~min}$ at an illumination distance of $5 \mathrm{~cm}$ at $25^{\circ} \mathrm{C}$. The illuminated viral suspension and nitrocellulose filter were vigorously washed, and the suspension was then serially diluted $\left(10^{0}-10^{-8}\right)$ by Minimum Essential Medium (MEM) supplement with TPCK-trypsin. Each diluted sample was used to infect Madin-Darby Canine Kidney (MDCK) cells in the presence of TPCK-trypsin at $37^{\circ} \mathrm{C}$ for 3 days. The end point of cytopathic effects (CPE) as 
small, round and degeneration was recorded. Virus sample without VUV illumination was used to infect MDCK as positive control and to determine the original viral load. Each test was conducted in triplicate.

\section{Data analysis}

For bacteria, $\log 10$ reduction of viable bacterial count in $\mathrm{CFU} / \mathrm{mL}$ was calculated by comparing control and post irradiation filters.

For influenza viruses, reductions at $\log 10\left(\mathrm{TCID}_{50}\right)$ was calculated similarly.

For each test, outliers were removed by Dixon's Q test at $95 \%$ significance level. The resultant $\log 10$ reduction in $\mathrm{CFU} / \mathrm{ml}$ of each bacterial strain and the resultant $\log 10$ reduction in $\mathrm{TCID}_{50}$ for each viral strain were plotted against disinfection durations, and error bars showing the data of the experiments that deviate from the corresponding mean value were also provided. MS Excel was used in all calculations and graph generation. A spreadsheet file containing raw data and intermediate calculations is provided in as a supplementary information file.

\section{Results}

\section{Escherichia coli ATCC25922 (E. coli)}

Initial inoculum sizes for $E$. coli in 10-fold diluted and 100-fold diluted 0.5 McFarland standard inoculums across triplicate experiment sets, presented in the Additional file 1 as Expt. 1 and Expt. 2, were $(1.9 \pm 0.6) \times 10^{7} \mathrm{CFU} / \mathrm{mL}$ and $(2.4 \pm 0.2) \times 10^{6} \mathrm{CFU} / \mathrm{mL}$, respectively. At $10 \mathrm{~min} \mathrm{VUV}$ light disinfection, the device was able to produce at least $6-\log 10$ reduction in viable bacterial count for 100 -fold diluted 0.5 McFarland standard inoculum. However, 10 min VUV light disinfection for 10-fold diluted 0.5 McFarland standard inoculum can only achieve a borderline to insufficient bactericidal activity with an average $2.4-\log 10$ growth reduction and $99.57 \%$ inhibition of bacterial growth (Fig. 2a and b). The results suggested that VUV light disinfection is much more effective against lower $E$. coli bacterial concentration. At 15 min disinfection, complete inhibition of bacterial growth was also observed in 10-fold diluted 0.5 McFarland standard inoculum, resulting in at least 6-log10 growth reduction (Fig. $2 \mathrm{a}$ and $\mathrm{b}$ ).

\section{Extended Spectrum Beta-Lactamase-producing E. coli (ESBL)} Initial bacterial counts of ESBL for 10-fold diluted and 100-fold diluted 0.5 McFarland standard inoculums across triple experimental sets, presented in the Additional file 1 as Expt. 3 and Expt. 4, were $(2.7 \pm 0.3) \times 10^{7} \mathrm{CFU} / \mathrm{mL}$ and $(3.2 \pm 0.7) \times 10^{6} \mathrm{CFU} / \mathrm{mL}$, respectively. It was observed that after 15-min disinfection, both 10-fold diluted and 100-fold diluted 0.5 McFarland standard inoculums were able to achieve complete inhibition of bacterial growth, resulting in at least $6-\log 10$ growth reduction (Fig. 2a and b). However, at 10-min of disinfection time, although, the device was able to produce at least 6 - $\log 10$ reduction of bacterial growth for the 100-fold diluted inoculum, VUV light was only able to produce a borderline to insufficient bactericidal effect for the 10-fold diluted 0.5 McFarland standard inoculum. The test only demonstrated an average of $2.96-\log 10$ reduction with $99.63 \%$ growth inhibition. The results have demonstrated that VUV light is more effective against a lower concentration of ESBL.

\section{Methicillin-resistant Staphylococcus aureus (MRSA)}

Initial bacterial counts of MRSA for 10-fold diluted and 100-fold diluted 0.5 McFarland standard inoculums across triple experiment sets, presented in the Additional file 1 as Expt. 5 and Expt. 6, were $(3.7 \pm 0.9) \times 10^{6} \mathrm{CFU} / \mathrm{mL}$ and
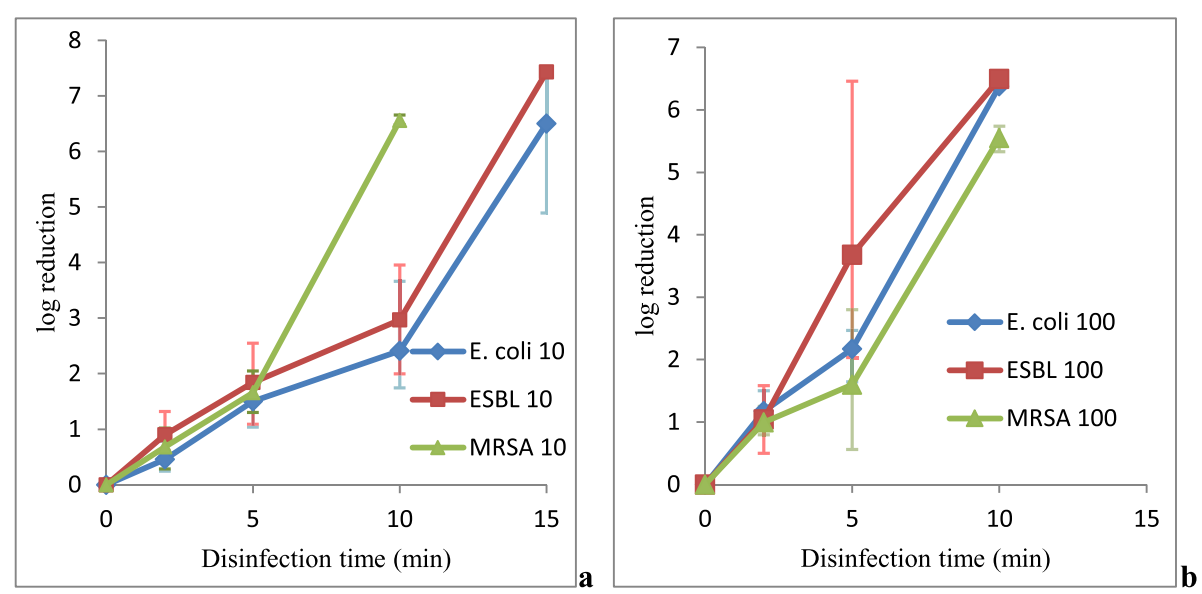

Fig. 2 VUV light disinfection against E. coli, ESBL and MRSA. Both 10-fold (a) and 100-fold (b) diluted 0.5 McFarland standard inoculums of E. coli (denoted by E. coli with the dilution ratio behind), ESBL (denoted by ESBL with the dilution ratio behind) and MRSA (denoted by MRSA with the dilution ratio behind) were subjected to VUV light disinfection. The $\log 10$ (CFU/mL reduction) were plotted against the time of disinfection. Data were plotted as the means of triplicate biological replicates \pm error 
$(3.8 \pm 1.7) \times 10^{5} \mathrm{CFU} / \mathrm{mL}$, respectively. At $10 \mathrm{~min}$ of $\mathrm{VUV}$ light disinfection, the bacteria of the 10-fold diluted and the 100-fold diluted 0.5 McFarland standard inoculums were completely inhibited, resulting in at least $5-\log 10$ growth reduction (Fig. $2 \mathrm{a}$ and $\mathrm{b}$ ).

\section{Mycobacterium tuberculosis (MTB)}

As defined in previous sections, disinfection time against bacteria was considered sufficient when a minimum 3$\log 10$ reduction of viable bacterial count was observed. For mycobactericidal activity, a 5 - $\log 10$ reduction in viable bacterial load is required due to the highly infectious nature of MTB. In other words, a minimum of $5-\log 10$ viable bacterial load would be required for a valid experimental set. The average bacterial concentration for McFarland standard 0.5 MTB inoculum was only $(3-5) \times 10^{6} \mathrm{CFU} /$ $\mathrm{mL}$ according to our previous experiments (data not shown). When the bacterial inoculum was diluted by 100fold, the bacterial concentration would only be around $10^{4} \mathrm{CFU} / \mathrm{mL}$. The bacterial load could be too low and it was incapable of illustrating $5-\log 10$ growth reduction. The experiment was therefore conducted with a higher bacterial concentration and more detailed disinfection time as compared to the tests of other bacteria. 0.5 McFarland standard and 10-fold diluted 0.5 McFarland standard inoculums were used and irradiated by VUV for 10 , 20, 30 and $45 \mathrm{~min}$. Initial bacterial counts for 0.5 McFarland standard and the 10-fold diluted 0.5 McFarland standard MTB inoculums were $(4.4 \pm 1.7) \times 10^{6} \mathrm{CFU} /$ $\mathrm{mL}$ and $(1.2 \pm 0.2) \times 10^{5} \mathrm{CFU} / \mathrm{mL}$, respectively, presented in the Additional file 1 as Expt. 7 and Expt. 8.

Gradual reduction in bacterial count was observed with prolonged VUV disinfection time. Complete inhibition of bacterial growth was observed after 30 min VUV light disinfection. At 20 min VUV illumination, VUV light was able to produce an average of $4-\log 10$ and $3.6-\log 10$ reduction in 0.5 McFarland standard and the 10-fold diluted 0.5 McFarland standard inoculums, respectively (Fig. 3).

In the present study, we have demonstrated that VUV light disinfection can achieve complete inactivation of MTB growth after $30 \mathrm{~min}$ disinfection regardless of the bacterial concentration. Meanwhile at $20 \mathrm{~min}$, VUV light disinfection can only result in a minimum of $3-\log 10$ reduction in bacterial count, which is much longer when compared to the $E$ coli, ESBL and MRSA experiments described in previous sections. Previous studies $[19,35,36]$ showed that mycobacterial species are generally more resistant to UV disinfection, but are subject to a better disinfection effect under VUV light. It seemed that VUV light disinfection was less effective against MTB at a lower bacterial concentration.

\section{Influenza viruses $\mathrm{H} 1 \mathrm{~N} 1$ and $\mathrm{H} 3 \mathrm{~N} 2$}

Meanwhile for viral disinfection, test results were considered acceptable when the viral-induced cytotoxic effect is

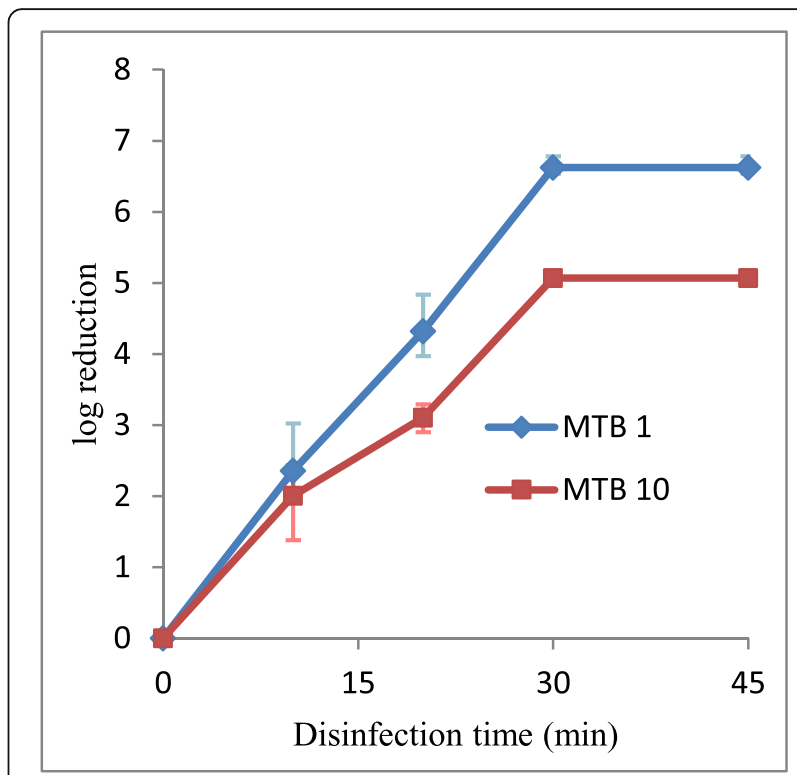

Fig. 3 VUV light disinfection against MTB. The experimental sets were conducted on $0.5 \mathrm{McF}$ arland standard inoculum (denoted by MTB 1) and 10-fold diluted 0.5 McFarland standard inoculum (denoted by MTB 10). The $\log 10$ (CFU/mL reduction) were plotted against the time of disinfection. Data were plotted as the means of triplicate biological replicates \pm error

indistinguishable from test agent-induced cytotoxic effects. VUV light disinfection time against viruses would be considered sufficient when a minimum of 3-log10 reduction in viral-induced cytotoxicity in titer was achieved. Therefore, the infectious viruses recovered from the positive controls must be $\geq 4-\log 10$ for valid viricidal test results. To determine the disinfection efficacy of VUV light against seasonal influenza viruses, two common influenza A viruses, H3N2 and $\mathrm{H} 1 \mathrm{~N} 1$, causing seasonal epidemics were used. In the current study, initial viral loads for both H1N1 and H3N2, presented in the Additional file 1 as Expt. 9 and Expt. 10, were $5.4 \pm 0.4 \log 10\left(\mathrm{TCID}_{50} / \mathrm{mL}\right)$ and $5.1 \pm 0.8 \log 10(\mathrm{~T}$ $\mathrm{CID}_{50} / \mathrm{mL}$ ), respectively.

For samples with $\log 10\left(\mathrm{TCID}_{50} / \mathrm{mL}\right)$ less than 1.5 , the titer was treated as 0.5 for $\log$ reduction calculation and graph plotting purpose.

At $5 \mathrm{~min}$ of illumination, VUV light can inactivate H1N1 and H3N2 by 2.2- and 3.0-log10 folds viral load $\left(\mathrm{TCID}_{50}\right)$, respectively (Fig. 4). When the VUV illumination time was extended to $20 \mathrm{~min}$, more than $4-\log 10$ reductions in $\mathrm{TCID}_{50}$ of both seasonal influenza A viruses were observed.

\section{Discussion}

High-energy vacuum-UV light is efficient in disinfection. Similar to other UV disinfection mechanisms, direct illumination of VUV could result in the formation of new bonds between adjacent nucleotides, causing photochemical damage 


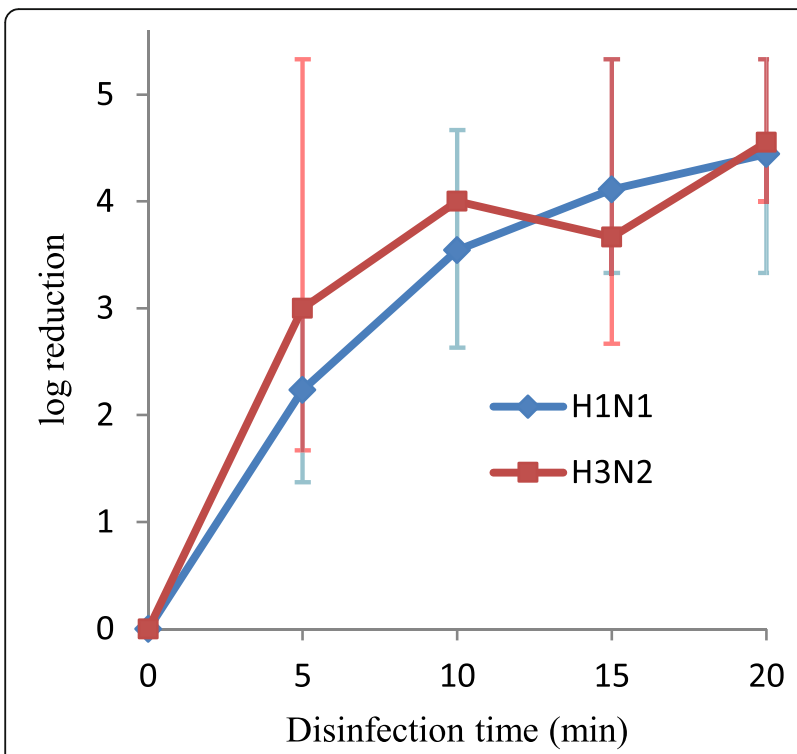

Fig. $4 \mathrm{VUV}$ light disinfection against $\mathrm{H} 1 \mathrm{~N} 1$ and $\mathrm{H} 3 \mathrm{~N} 2$ influenza $\mathrm{A}$ viruses. The $\log 10\left(\mathrm{TCID}_{50} / \mathrm{mL}\right.$ reduction) was plotted against disinfection time

on DNA strands and eventually inactivating the replication of microorganisms.

In addition, the high-energy VUV could also lead to the formation of both $\mathrm{OH}$ radicals and $\mathrm{O}_{3}$, which diffuse into anywhere that is shielded from direct UV irradiation and inhibit the growth of microorganism. This explained the excellent bactericidal efficiency of VUV light disinfection even in the presence of the opaque nitrocellulose filter. Our result has further revealed the potential of VUV light to provide a thorough disinfection, even for dust particles and large aerosols contaminated with pathogens where direct UV illumination cannot penetrate.

In this study, we demonstrated that VUV light disinfection is effective against Escherichia coli, Extended Spectrum Beta-Lactamase-producing E. coli and Methicillin-resistant Staphylococcus aureus. For the best tested situation, with the criterion of 3-log10 inactivation of bacteria, valid germicidal result can be achieved with $\leq 10 \mathrm{~min}$ of VUV treatment. Additionally, more than $5-\log 10$ reduction in viable plate count can be attained below 15 min of disinfection.

In the disinfection tests against seasonal influenza viruses $\mathrm{H} 1 \mathrm{~N} 1$ and $\mathrm{H} 3 \mathrm{~N} 2$, we also demonstrated that viral load could be effectively reduced by $4-\log 10$ folds after 20 min VUV illumination and this also satisfied the criterion of valid germicidal result. Additionally, more than $3-\log 10$ reduction in viral load can be attained with $<10$ min of treatment.

Mycobacterium tuberculosis, on the other hand, required a more intense disinfection.

At 20 min disinfection, VUV light disinfection could only result in a $3-\log 10$ reduction in viable plate count. This is insufficient according to our 5 - $\log 10$ reduction criterion for mycobacterial disinfection. It was only after 30 min of disinfection that the required $5-\log 10$ reduction of Mycobacterium tuberculosis viable bacterial load could be achieved regardless of the bacterial concentration. This is concordant to previous studies [19, 35, 36] where mycobacterial species were generally more resistant to UV disinfection. This is probably accounted by the thicker lipid cell wall in Mycobacterium species.

The tested variations in concentrations of bacteria did not manifest a trend in the rate of inactivation. For $E$. coli and ESBL, higher bacterial concentration resulted in lower rates of inactivation. Experiments with MTB showed a different trend. Nevertheless, no obvious trend was showed in the experiments with MRSA.

From literature, various research teams reported the UV dosages required attaining 99.9\% (3-log) inactivation of various bacteria or viruses under light from low pressure mercury vapour lamps. For example, the UV dosages in $\mathrm{mJ} / \mathrm{cm}^{2}$ for 3-log inactivation of T7 phage, $E$ coli., Staphylococcus aureus, Mycobacterium avium and Mycobacterium phlei are 10 [37], 5 [37], 9 [34], 18 [20] and 158 [34], respectively. Most of their experiments were conducted with bacteria and viruses virtually unprotected. In our experiment, attaining 3-log inactivation typically required $10 \mathrm{~min}$. Considering that our equipment provided 21 and $2.3 \mathrm{~mW} / \mathrm{cm}^{2}$ light power at 254 $\mathrm{nm}$ and $185 \mathrm{~nm}$, and the total UV power is $\sim 23 \mathrm{~mW} /$ $\mathrm{cm}^{2}$. The UV dosage of $10 \mathrm{~min}$ illumination is $\sim 14,000$ $\mathrm{mJ} / \mathrm{cm}^{2}$, far higher than the usual values. This could be the consequence of our testing condition created by loading the suspended bacteria or viruses onto nitrocellulose filter paper. Some bacteria were actually protected from direct UV light by the shading effect of filter paper which is different from the testing setup in the literature.

In order to provide sufficient disinfection against all the microorganisms we included in this study, we suggested the use of Mycobacterium reduction as a benchmark test for future disinfection instrument designs that incorporates the VUV light system.

Although, the disinfection under the environment with a moderate barrier to light was successful, there are limitations in the present study. The current pilot study on the disinfection efficacy of VUV light disinfection was conducted in laboratory-controlled conditions. For example, due to safety consideration, device type testing on aerosolized bacteria and viruses is not possible. All bacterial and viral inoculums were prepared in liquid suspension and illuminated by VUV on a Petri dish, which differed from actual environmental settings.

\section{Conclusion}

Airborne pathogens are important indoor air quality concerns. A good and reliable disinfection system is a must to maintain good indoor air quality. Vacuum-UV 
lamps with ozone production were found to be effective for inactivating various human pathogens. With the best tested situation, 3- $\log 10$ inactivation of Escherichia coli, Extended Spectrum Beta-Lactamase-producing E. coli, Methicillin-resistant Staphylococcus aureus and seasonal influenza viruses can be achieved with $\leq 10 \mathrm{~min}$ of VUV treatment except Mycobacterium tuberculosis which needed about $20 \mathrm{~min}$. This demonstrated the high resistance against UV disinfection of MTB. Valid germicidal results, reflected with $3-\log 10$ inactivation for bacteria, 4- $\log 10$ inactivation for viruses and $5-\log 10$ inactivation for MTB, can be obtained with all tested pathogens. The duration of VUV treatment required for valid germicidal result of most of the bacteria was $\leq 10 \mathrm{~min}$ while MTB needed about $30 \mathrm{~min} .20 \mathrm{~min}$ was adequate for the influenza viruses. This indicated that VUV light is an effective approach against different environmental and pathogenic microorganisms, and can potentially be used for airpurifying units in future ventilation systems.

\section{Supplementary information}

Supplementary information accompanies this paper at https://doi.org/10. 1186/s12879-020-4847-9.

Additional file 1. This file contains all data supporting the findings in this study which is a spreadsheet file containing raw data and intermediate calculations.

\section{Abbreviations}

ATCC: American type culture collection; BHI: Brain heart infusion; CFU: Colony-forming units; CPE: Cytopathic effect; E. coli: Escherichia coli; ESBL: Extended spectrum beta-lactamase; IAQ: Indoor air quality; MDCK: Madin-Darby canine kidney; MEM: Minimum essential medium; MRSA: Methicillin-resistant Staphylococcus aureus; MTB: Mycobacterium tuberculosis; $\mathrm{O}_{3}$ : Ozone; OADC: Oleic acid-albumin-dextrose-catalase; $\mathrm{OH}$ : Hydroxyl radical; PBS: Phosphate-buffered saline; $\mathrm{TCID}_{50}$ : Tissue culture infective dose 50; TPCK: 6-(1-tosylamido-2-phenyl) ethyl chloromethyl ketone; UV: Ultraviolet; UVC: Ultraviolet C; VUV: Vacuum ultraviolet

\section{Acknowledgements}

Not applicable.

\section{Authors' contributions}

WS was a major contributor in writing and editing the manuscript. WCY was responsible for the experimental investigation and analysis. $\mathrm{HH}$ provided comments on the experiment setup and manuscript. DYCL coordinated the test and approved the final manuscript. All authors read and approved the final manuscript.

\section{Funding}

Funding was provided by the National Natural Science Foundation of China (NSFC) and The Research Grants Council (RGC) of Hong Kong. The funding bodies were not involved in the preparation of the manuscript.

\section{Availability of data and materials}

All data supporting the findings in this study are contained within the supplementary information files.

\section{Ethics approval and consent to participate}

Not applicable.

\section{Consent for publication}

Not applicable.

\section{Competing interests}

The authors declare that they have no competing interests.

\section{Author details}

${ }^{1}$ Department of Mechanical Engineering, The University of Hong Kong, Hong Kong, China. ${ }^{2}$ Department of Microbiology, The University of Hong Kong, Hong Kong, China. ${ }^{3}$ School of Environmental Science and Engineering, Sun Yat-sen University, Guangzhou, China.

Received: 29 July 2019 Accepted: 3 February 2020

Published online: 11 February 2020

\section{References}

1. Kosonen $\mathrm{R}$, Tan $\mathrm{F}$. The effect of perceived indoor air quality on productivity loss. Energy Buildings. 2004;36(10):981-6.

2. Weinstein RA, Bridges CB, Kuehnert MJ, Hall CB. Transmission of influenza: implications for control in health care settings. Clin Infect Dis. 2003;37(8): 1094-101.

3. Wang T, MacGregor S, Anderson J, Woolsey G. Pulsed ultra-violet inactivation spectrum of Escherichia coli. Water Res. 2005;39(13):2921-5.

4. Huang $H$, Leung DYC, Li G, Leung MK, Fu X. Photocatalytic destruction of air pollutants with vacuum ultraviolet (VUV) irradiation. Catal Today. 2011; 175(1):310-5.

5. Batakliev T, Georgiev $\vee$, Anachkov M, Rakovsky S. Ozone decomposition. Interdiscip Toxicol. 2014;7(2):47-59.

6. Wu M, Leung DYC, Zhang Y, Huang H, Xie R, Szeto W, Li F. Toluene degradation over $\mathrm{Mn}-\mathrm{TiO} 2 / \mathrm{CeO} 2$ composite catalyst under vacuum ultraviolet (VUV) irradiation. Chem Eng Sci. 2019;195:985-94.

7. Schalk S, Adam V, Arnold E, Brieden K, Voronov A, Witzke H-D. UV-lamps for disinfection and advanced oxidation-lamp types, technologies and applications. IUVA News. 2005;8(1):32-7.

8. Brickner PW, Vincent RL, First M, Nardell E, Murray M, Kaufman W. The application of ultraviolet germicidal irradiation to control transmission of airborne disease: bioterrorism countermeasure. Public Health Rep. 2003; 118(2):99.

9. Escombe AR, Moore DA, Gilman RH, Navincopa M, Ticona E, Mitchell B, Noakes C, Martínez C, Sheen P, Ramirez R. Upper-room ultraviolet light and negative air ionization to prevent tuberculosis transmission. PLoS Med. 2009:6(3):e1000043.

10. Xu P, Peccia J, Fabian P, Martyny JW, Fennelly KP, Hernandez M, Miller SL. Efficacy of ultraviolet germicidal irradiation of upper-room air in inactivating airborne bacterial spores and mycobacteria in full-scale studies. Atmos Environ. 2003;37(3):405-19.

11. Goldstein MA, Tauraso NM. Effect of formalin, $\beta$-propiolactone, merthiolate, and ultraviolet light upon influenza virus infectivity, chicken cell agglutination, hemagglutination, and antigenicity. Appl Environ Microbiol. 1970;19(2):290-4.

12. Walker CM, Ko G. Effect of ultraviolet germicidal irradiation on viral aerosols. Environ Sci Technol. 2007;41(15):5460-5.

13. Green CF, Scarpino PV. The use of ultraviolet germicidal irradiation (UVGI) in disinfection of airborne bacteria. Environ Eng Policy. 2001;3(1):101-7.

14. Peccia J, Werth HM, Miller S, Hernandez M. Effects of relative humidity on the ultraviolet induced inactivation of airborne bacteria. Aerosol Sci Technol. 2001;35(3):728-40

15. Chumpolbanchorn K, Suemanotham N, Siripara N, Puyati B, Chaichoune K. The effect of temperature and UV light on infectivity of avian influenza virus (H5N1, Thai field strain) in chicken fecal manure; 2006.

16. Hollaender A, Oliphant JW. The inactivating effect of monochromatic ultraviolet radiation on influenza virus. J Bacteriol. 1944;48(4):447.

17. Lai K-M. Using selective media to assess aerosolization damage and ultraviolet germicidal irradiation susceptibility of Serratia marcescens. Aerobiologia. 2005;21(3-4):173-9.

18. Nardell EA, Bucher SJ, Brickner PW, Wang C, Vincent RL, Becan-McBride K, James MA, Michael M, Wright JD. Safety of upper-room ultraviolet germicidal air disinfection for room occupants: results from the tuberculosis ultraviolet shelter study. Public Health Rep. 2008;123(1):52-60.

19. Collins FM. Relative susceptibility of acid-fast and non-acid-fast bacteria to ultraviolet light. Appl Microbiol. 1971;21(3):411-3.

20. Shin G-A, Lee J-K, Freeman R, Cangelosi GA. Inactivation of Mycobacterium avium complex by UV irradiation. Appl Environ Microbiol. 2008;74(22):7067-9. 
21. Rutala WA, Gergen MF, Weber DJ. Room decontamination with UV radiation. Infect Control Hosp Epidemiol. 2010;31(10):1025-9.

22. Truman RW, Gillis TP. The effect of ultraviolet light radiation on Mycobacterium leprae. Int I Lepr Other Mycobact Dis. 2000;68(1):11-7.

23. Mofidi AA, Baribeau H, Rochelle PA, De Leon R, Coffey BM, Green JF. Disinfection of Cryptosporidium parvum with polychromatic UV light. J-Am Water Works Assoc. 2001;93(6):95-109.

24. Yaun BR, Sumner SS, Eifert JD, Marcy JE. Response of Salmonella and Escherichia coli 0157: H7 to UV energy. J Food Prot. 2003;66(6):1071-3.

25. Zimmer J, Slawson R, Huck P. Inactivation and potential repair of Cryptosporidium parvum following low-and medium-pressure ultraviolet irradiation. Water Res. 2003;37(14):3517-23.

26. Jinadatha C, Villamaria FC, Restrepo Ml, Ganachari-Mallappa N, Liao I-C, Stock EM, Copeland LA, Zeber JE. Is the pulsed xenon ultraviolet light notouch disinfection system effective on methicillin-resistant Staphylococcus aureus in the absence of manual cleaning? Am J Infect Control. 2015;43(8): 878-81.

27. Hassen A, Mahrouk M, Ouzari H, Cherif M, Boudabous A, Damelincourt JJ. UV disinfection of treated wastewater in a large-scale pilot plant and inactivation of selected bacteria in a laboratory UV device. Bioresour Technol. 2000;74(2):141-50.

28. Sommer R, Lhotsky M, Haider T, Cabaj A. UV inactivation, liquid-holding recovery, and photoreactivation of Escherichia coli O157 and other pathogenic Escherichia coli strains in water. J Food Prot. 2000;63(8):1015-20.

29. Jinadatha C, Quezada R, Huber TW, Williams JB, Zeber JE, Copeland LA. Evaluation of a pulsed-xenon ultraviolet room disinfection device for impact on contamination levels of methicillin-resistant Staphylococcus aureus. BMC Infect Dis. 2014;14(1):187.

30. Kim J, Jang J. Inactivation of airborne viruses using vacuum ultraviolet photocatalysis for a flow-through indoor air purifier with short irradiation time. Aerosol Sci Technol. 2018;52(5):557-66

31. Ramsay IA, Niedziela J-C, Ogden ID. The synergistic effect of excimer and low-pressure mercury lamps on the disinfection of flowing water. J Food Prot. 2000;63(11):1529-33.

32. Wang D, Oppenländer T, El-Din MG, Bolton JR. Comparison of the disinfection effects of vacuum-UV (VUV) and UV light on Bacillus subtilis spores in aqueous suspensions at 172, 222 and $254 \mathrm{~nm}$. Photochem Photobiol. 2010;86(1):176-81.

33. Zoschke $\mathrm{K}$, Börnick $\mathrm{H}$, Worch E. Vacuum-UV radiation at $185 \mathrm{~nm}$ in water treatment-a review. Water Res. 2014;52:131-45.

34. Christofi N, Misakyan M, Matafonova G, Barkhudarov E, Batoev V, Kossyi I, Sharp J. UV treatment of microorganisms on artificially-contaminated surfaces using excimer and microwave UV lamps. Chemosphere. 2008;73(5): 717-22.

35. Peccia J, Hernandez M. UV-induced inactivation rates for airborne Mycobacterium bovis BCG. J Occup Environ Hyg. 2004;1(7):430-5.

36. Bohrerova Z, Linden KG. Assessment of DNA damage and repair in Mycobacterium terrae after exposure to UV irradiation. J Appl Microbiol. 2006;101(5):995-1001.

37. Bohrerova Z, Shemer $H$, Lantis $R$, Impellitteri CA, Linden KG. Comparative disinfection efficiency of pulsed and continuous-wave UV irradiation technologies. Water Res. 2008;42(12):2975-82.

\section{Publisher's Note}

Springer Nature remains neutral with regard to jurisdictional claims in published maps and institutional affiliations.

Ready to submit your research? Choose BMC and benefit from:

- fast, convenient online submission

- thorough peer review by experienced researchers in your field

- rapid publication on acceptance

- support for research data, including large and complex data types

- gold Open Access which fosters wider collaboration and increased citations

- maximum visibility for your research: over $100 \mathrm{M}$ website views per year

At BMC, research is always in progress.

Learn more biomedcentral.com/submissions 